Georgia State University

ScholarWorks @ Georgia State University

\title{
Migrant Entrepreneurship in China: Entrepreneurial Transition and Firm Performance
}

\author{
Cathy Yang Liu \\ Georgia State University, cyliu@gsu.edu \\ Lin Ye \\ Sun Yat-Sen University \\ Bo Feng \\ Georgia State University
}

Follow this and additional works at: https://scholarworks.gsu.edu/uwrg_workingpapers

\section{Recommended Citation}

Liu, Cathy Yang; Ye, Lin; and Feng, Bo, "Migrant Entrepreneurship in China: Entrepreneurial Transition and Firm Performance" (2017). UWRG Working Papers. 114.

https://scholarworks.gsu.edu/uwrg_workingpapers/114

This Article is brought to you for free and open access by the Usery Workplace Research Group at ScholarWorks @ Georgia State University. It has been accepted for inclusion in UWRG Working Papers by an authorized administrator of ScholarWorks @ Georgia State University. For more information, please contact scholarworks@gsu.edu. 


\section{W. J. Usery Workplace Research Group Paper Series}

Working Paper 2017-9-7

September 2017

\section{Migrant Entrepreneurship in China: Entrepreneurial Transition and Firm Performance}

Cathy Yang Liu

Georgia State University

Lin Ye

Sun Yat-Sen University

Bo Feng

Georgia State University

ANDREW YOUNG SCHOOL 
Migrant Entrepreneurship in China: Entrepreneurial Transition and Firm Performance

Forthcoming, Small Business Economics

September 20, 2017

Cathy Yang LIU (corresponding author) Associate Professor

Andrew Young School of Policy Studies

Georgia State University Atlanta, GA USA

cyliu@gsu.edu

\author{
Lin YE \\ Professor \\ Center for Chinese Public Administration Research \\ School of Government \\ Sun Yat-Sen University \\ Guangzhou, China
}

Bo FENG

$\mathrm{Ph} . \mathrm{D}$. Student

Andrew Young School of Policy Studies

Georgia State University

Atlanta, GA USA 


\title{
Migrant Entrepreneurship in China:
}

\section{Entrepreneurial Transition and Firm Performance}

\begin{abstract}
China is experiencing rapid urbanization during which millions of migrants move from rural to urban areas. Recently, China initiated the national strategy of "mass entrepreneurship and innovation" to tap into the innovative potential and promote entrepreneurial development among the general public, with rural migrants being one of the targeted groups of this policy. This context calls for a better understanding of rural migrants' entrepreneurial formation and transition.
\end{abstract}

Using the 2012 and 2014 Chinese Labor-force Dynamics Survey (CLDS) data, we test the importance of human capital, social capital, and community trust on migrants' entrepreneurial entry with cross-sectional and panel data analyses. We find that rural migrants' entrepreneurship rates and entrepreneurial entry rates surpass both their urban resident and rural resident counterparts, indicating the active role they play in urban business landscape. While individual characteristics and social networks play similar roles in these three groups' entrepreneurial transition, rural migrants' business activities are particularly shaped by their perception of communities. Further analysis of migrant-owned businesses reveals their over-representation in main-street industries but their firm performances are on par with other businesses, suggesting their positive economic contribution in cities.

Keywords: migrant entrepreneurship, firm performance, China, Chinese Labor-force Dynamics Survey (CLDS) JEL codes: L25, L26, R23 


\section{Introduction}

China's urbanization and economic growth has received worldwide attention. As a substantial economic entity, the country's marketization benefits from a supportive public sector and the rapid expansion of its nonstate sector. Urban employment in state-owned enterprises (SOEs) has been declining since the mid-2000s while the self-employment sector is gaining momentum over the same period. To strengthen this trend, the Chinese government has initiated a series of policies to encourage entrepreneurial activities among both urban residents and migrant workers.

The Chinese State Council viewed entrepreneurial development as a channel to mitigate rising unemployment burden and create job opportunities for the migrant population (The State Council 2015). Coined as "Mass Entrepreneurship and Innovation", this policy aims to stimulate business development and entrepreneurial spirit among the general public, expand employment opportunities, increase personal income, as well as facilitate social and economic mobility. One of the targeted groups under the policy is migrant workers, a traditionally marginalized labor force in the Chinese society. For this particular group, the Opinion on Significantly Promoting Mass Entrepreneurship and Innovation Policies presented two types of support, encouraging them to either return to the countryside or remain in the city and start up private ventures.

These policies recognize the fact that migrants tend to be actively engaged in entrepreneurial activities and add substantially to the urban vitality in Chinese cities (Chen 2015). Existing literature on Western countries suggested that immigrants have higher tendency to participate in entrepreneurial activities than nativeborn residents due to their constraints in the labor market and/or keen entrepreneurial drive (Light 1972; Zhou 2004). Despite immigrants' language, legal and capital barriers, immigrant-owned businesses rise steadily in number and outperform native-owned businesses with respect to employment growth (but not payroll growth), making important contributions to the U.S. economy (Kerr and Kerr 2016). Rural migrants in Chinese cities might face similar constraints given their lack of hukou (local registration) status and its associated labor market and social service benefits ( $\mathrm{Li}$ 2006). The hukou system, or household registration system in China, assigns each person urban or rural status based primarily on place of birth and serves as an official tool to restrict rural- 
urban mobility. While this system is relaxed gradually, it still poses significant institutional constraints to rural migrants who are largely excluded from the social welfare package reserved for local residents, including unemployment insurance, healthcare, and social housing (Chan and Buckingham 2008) Should they face "blocked opportunities" from formal employment sectors that require urban hukou and high educational credentials, rural migrants might seek other paths to upward mobility, one being the pursuit of business ownership (Bates 1997).

Migrants with rural hukou status exhibit higher self-employment tendency than other groups such as locals and migrants with urban hukou status (Liu and Huang 2016), yet little is known about their distinctive entrepreneurial dynamics in cities. Also absent is the knowledge about their differences with individuals having urban hukou status and living in urban areas or with rural residents remaining in the countryside. It is reasonable to expect that migrant workers, as temporary residents in urban areas, are exposed to a different set of community factors that would necessarily shape their aspirations for an entrepreneurial path. These decisions, in turn, would determine the impact their entrepreneurial activities have on the urban spaces.

While migrant entrepreneurs would denote any entrepreneur who is not "local" and include those who migrate from other urban areas as well as from rural areas, the focus of our inquiry is rural migrant entrepreneurs who now reside in cities. By 2013, there were approximately 240 million migrants without local hukou in urban China and more than 80 percent of them were rural-to-urban migrants, and the rest were urbanto-urban migrants. Instead of treating migrants as a homogenous group in comparison to urban residents, we engage in a detailed analysis of entrepreneurial entry dynamics among the migrant workers. Very few studies to date have focused on this group and we contribute to this literature in three ways. First, we test the relationship between human capital, social capital, and community linkages on the likelihood of entrepreneurship, with particular focus placed on the heterogeneous effects across three groups: rural residents, urban residents, and rural migrants. Second, the longitudinal nature of CLDS enables us to address endogeneity concerns from previous cross-sectional analysis. We use panel data to further test these effects on rural migrants' entrepreneurial entry between 2012 and 2014. Last, we provide evidence on the impact migrant-owned- 
businesses exert on urban economic development along several dimensions: business duration, employment potential, payroll, and industrial sectors. While anecdotal evidence suggests that migrant owned businesses in cities tend to be small-scaled vendors resembling those of newly arrived immigrants in Western cities, these stereotypes remain to be tested. Overall, our attention to rural migrants offers a timely contribution to the extant literature on entrepreneurial transition and firm performance in urban China.

This article is organized as follows. The literature on entrepreneurial development, especially for migrants, in the western and Chinese context is reviewed to provide existing frameworks that inform our empirical analysis. Descriptive analyses are then performed to provide some patterns and trends regarding geographic and group variations on entrepreneurial rates and entry in China, followed by regression models to test the above-mentioned research questions. Policy recommendations are also offered.

\section{Literature Review}

\section{Immigrant Entrepreneurial Entry and Businesses in Western Context}

There is a growing literature on the entry dynamics and firm performances of minority-owned and immigrant-owned businesses in the Western context from various academic disciplines (e.g. Waldinger et al. 1990; Rath and Kloosterman 2000). These studies found that immigrants are more entrepreneurial and have higher self-employment rates than the native-born population (Borjas 1986; Yuengert 1995; Fairlie 2012) though the exact explanations for such differences are varied. Both push and pull factors have been identified to explain immigrants' entrepreneurial behavior as they are either pushed into self-employment given blocked opportunities and difficulty to assimilate into the formal labor market or pulled into entrepreneurship with their relatively high risk taking tendency and innate entrepreneurial spirit that could be rooted in their home countries and their migratory journey (Yuengert 1995 Constant and Zimmermann 2006). Recent evidence from the United Kingdom and the Netherlands suggested that immigrants are more pulled than pushed into starting businesses (Basu 1998; Kloosterman 2003). 
In examining the relative importance of human, financial, and cultural capital in shaping individuals' entrepreneurial entry, Kim, Aldrich and Lester (2006) found human capital as measured by education and experience is a significant predictor of business activities and the same applies to immigrants (Borjas 1986; Peroni et al. 2016). Social capital and social networks are crucial capital for immigrants in their adaptation to the life and work of the host country (Wilson and Portes 1980) as they rely on these weak and strong ties of family and community members for essential entryways into housing, employment, and other opportunities. In the process of business entry, informal networks of advice, information and finance also played important roles in stimulating entrepreneurial development among minority groups and immigrants (Basu 1986).

Besides human capital characteristics and social networks, studies in this area further emphasize the role of personal motivation and communities in immigrants' business startup behavior. For example, Liu (2012)'s analysis of minority groups' entrepreneurial entry shows that black and Hispanic nascent entrepreneurs are highly driven by a range of motivational factors to become entrepreneurs including autonomy, wealth, achievement, and respect. Immigrant entrepreneurs also tend to draw valuable resources from their respective communities in their business formation process, especially when they are constrained financially and culturally in a new environment (Light 1972; Zhou 2004). Termed as "ethnic enclave", these concentrated immigrant neighborhoods provide workers and clients with the type of goods and services immigrant entrepreneurs serve, financial and social support systems, as well as nurturing environments with cultural familiarity. In turn, ethnic businesses contribute substantially to the economic vitality and social cohesion of these communities (Liu, Miller and Wang 2014).

The stereotypical image of immigrant-owned businesses in the Western context depicts small-scale main-street businesses that feature low capital, harsh working conditions and very limited growth potential (Barrett et al 1996). Such an image is linked to earlier accounts that immigrants turn to self-employment as they are blocked in the formal labor market due to lack of formal education from host country and language proficiency (Light 1972; Zhou 2004 for review). Immigrants are also foreign to local business system and culture, lack basic training in owning a business in a new country, have low credit worthiness or asset to back 
up loan applications, as well as little institutional knowledge in dealing with formal financial instruments. Many of them may not even have legal resident status to access basic services (Fairlie 2012). Only recently has research started to acknowledge high-skilled immigrant entrepreneurship, their presence in high-tech and innovation, as well as their unique position to engage in transnational activities (Wang and Liu 2015).

\section{Migrant Entrepreneurial Entry and Businesses in Chinese Context}

China's private sector experienced gradual growth after reform and open-up in 1978. The hukou system which determines one's legal residence based on place of birth also has the effect of creating a segmented urban labor market once large scale rural-to-urban migration commenced (Fan 2003). Without urban hukou, rural migrants are not eligible to participate in certain employment sectors and are low on the job hierarchy in this two-tiered labor market, resulting in their relatively low occupational attainment and wage levels as compared to urban residents (Meng and Zhang 2001). Given their position in the labor market, migrants might turn to more informal occupations and start their own businesses.

Current literature on Chinese entrepreneurship emphasized the role of human capital and social capital in explaining entrepreneurial entry. Using a national urban household survey, Yueh (2009) found that those who are not Communist Party members and had unemployment experiences are more likely to start their own businesses. Interestingly, Chinese urban entrepreneurs were less-educated compared to their wage-earning counterparts, which is contrary to the western experience (Kim, Aldrich and Keister 2006). Studies that applied social capital theory to explaining entrepreneurship in China consistently find that a larger web of connection facilitates entrepreneurial formation (Knight and Yueh 2008; Zhang and Zhao 2015). Using a specifically designed survey in urban China, Djankov et al (2006) found that entrepreneurs are more likely to have family members or friends who have entrepreneurial experiences. A very recent paper by Liu and Huang (2016) took a different perspective in analyzing the new wave of entrepreneurs in urban China by distinguishing opportunity entrepreneurs who were pulled into entrepreneurship given opportunities from necessity entrepreneurs who were pushed into self-employment due to unemployment. 
Despite the policy attention paid to migrant workers in Chinese cities, few studies to our knowledge have systemically examined migrant entrepreneurship dynamics as compared to urban residents and their business establishments. In distinguishing the patterns of self-employment between rural and urban workers in China, Cui et al (2013) argued that rural migrants become self-employed to avoid low-pay city jobs as an alternative path of economic assimilation though the institutional barriers associated with lack of urban hukou might result in their lower-pay. Zhang and Zhao (2015) used instrumental variable to measure social-family network and found that rural migrants with larger social-family networks are more likely to be self-employed. Both studies used cross-sectional data which may not be able to accurately capture the factors that exist prior to the entrepreneurial entry point.

Like immigrants in the Western context, rural migrants in Chinese cities who have relatively low human and financial capital might also turn to community connections as important source for information, advice, and even capital and resources in their business formation process. This is particularly true in an institutional environment where they cannot access formal capital, insurance, business contracts, and legal protection (Yueh, 2012). Without hukou, migrants cannot formally participate in civil, legal and business affairs, including settling law suits or contracts disputes. In this sense, they do resemble illegal immigrants in the Western context to some extent though their "illegality" only applies to their identity in the cities, but not the rural areas where they come from. One interesting case study documented the vibrant and flexible garment manufacturing cluster formed in Xiaohubei (Little Hubei) neighborhood in Guangzhou where community ties enable migrants to adapt to the local economy through self-employment and small business establishments (Liu et al, 2015).

Given all the above discussions, we recognize that while migrant workers in China share some similarity with immigrants in Western countries, they also bear distinctive circumstances in their entrepreneurial activities. Therefore, we hypothesize that migrant workers with greater personal drive, larger social networks and greater community assets are more likely to become entrepreneurs and that the importance of social networks and community assets would be more pronounced for migrants than for urban residents. However the association between human capital and entrepreneurial entry can go in both directions. We also expect that their 
businesses might be smaller in scale in terms of employment and payroll, concentrate in main-street industrial sectors and have shorter business duration.

\section{Data and Methodology}

\section{Data and Background}

Our main data source is the China Labor-force Dynamics Survey (CLDS), a nationally representative survey conducted by the Center for Social Survey at Sun Yat-Sen University. The survey is administered biennially and is designed to track the current status and the dynamic changes of the Chinese labor force with a multistage cluster, stratified, PPS (Probability Proportional to Size) sampling design. By the time of this study, CLDS has finalized the first two waves (2012 and 2014) of data collection, with twenty-four provinces and four cities or direct municipalities (hereinafter administrative divisions) represented in the study. ${ }^{1}$ CLDS has detailed information on correspondents' demographic characteristics, economic activities, health status, social mobility, community context, among others. While attrition happens as typical among panel data, close to 60 percent of CLDS survey participants from the 2012 wave were successfully tracked in the 2014 wave. ${ }^{2}$ The resulting dataset has a sample size of 16,253 in 2012 and 23,594 in 2014, and over 9,000 are included in the panel. The following analyses are built upon both the cross-sectional and the longitudinal portions of CLDS.

[Table 1 about here]

[Figure 1 about here]

Entrepreneurship can have different definitions and it is not clear how it is differentiated from owners or even the self-employed (Aldrich and Waldinger 1990). Self-employment in the U.S. context includes those in own incorporated or unincorporated businesses and thus both employers and nonemployers. In studies that

\footnotetext{
${ }^{1}$ Sampling framework, parameter design, coding scheme and additional information of the data can be found at http://engcss.sysu.edu.cn/ . Provinces include: Hebei, Shanxi, Liaoning, Jilin, Heilongjiang, Jiangsu, Zhejiang, Anhui, Fujian, Jiangxi, Shandong, Henan, Hubei, Hunan, Guangdong, Guangxi, Sichuan, Guizhou, Yunnan, Gansu, Qinghai, Ningxia, Xinjiang and Inner Mongolia; Direct municipalities are: Beijing, Tianjin, Shanghai, and Chongqing.

2 The overall retention rate of 60 percent compares favorably to the retention rates usually reported in other studies. Sample composition did not change significantly between 2012 and 2014 along the dimensions we consider in the analysis. While we do not rule out potential biases induced by the differential attrition, CLDS has redesigned survey weight to make the panel sample nationally representative. We include this weight in the panel sample analysis to ward off remaining biases.
} 
utilize individual and household based surveys, self-employment is frequently used as a proxy for entrepreneurship (Yueh 2009; Liu 2012). Following prior studies, we use entrepreneurship and self-employment interchangeably and define entrepreneurs as individuals who are either self-employed or have started their businesses as employers. For those employed by others, work in the agricultural sector, or unemployed at the time of the survey, we group them as non-entrepreneurs. We restrict our analyses to labor force participants aged between 16 and 70. Table I and Figure 1a and 1b present each administrative division's share of survey participants and their respective entrepreneurship rates. The share of survey participants by administrative divisions in CLDS represents their overall population distribution well. Guangdong province has the highest share in 2012 and 2014, followed by Henan and Shandong. In terms of overall entrepreneurship rate, Jiangxi ranks the highest at 24 percent in 2012 and 21 percent in 2014, followed by Fujian (21 percent and 18 percent respectively) and Zhejiang (19 percent and 17 percent respectively). Overall, the sample entrepreneurship rate is consistent at 12 percent in both 2012 and 2014, largely mirroring the entrepreneurship rate reported by the National Bureau of Statistics of China. ${ }^{3}$

\section{Variables and Descriptive Statistics}

We use two sets of information to define an individual's migrant status - current hukou status and current living place. People with rural hukou are not entitled to certain job sectors, social services and welfare programs in cities and might be subject to certain institutional constraints. This identity, together with the individual's current living place, determines his/her migrant status. We categorize our sample into three groups: rural migrant, rural resident, and urban resident. An individual is defined as a rural resident if he/she has a rural hukou and lives in the rural area. An individual is an urban resident if he/she has urban hukou and lives in the urban area. Rural migrants are those with rural hukou but live in the urban area ${ }^{4}$

[Table 2 about here]

\footnotetext{
${ }^{3}$ According to the 2012 and 2014 National Bureau of Statistics of China, the entrepreneurial rate were $11 \%$ and $13 \%$ respectively.

${ }^{4}$ We exclude individuals with urban hukou but live in rural areas as they are very small in number.
} 
Panel A of Table 2 provides a first look at the entrepreneurship rates across three identified groups in 2012 and 2014. In both years, rural migrants have the highest rates among all groups, at 16.9 percent and 19.1 percent respectively. At the same time, their rates grew the fastest during this time period. Urban residents have the lowest rates in both years, at 9.7 percent and 10.8 percent respectively, possibly due to their advantage in securing stable employment. These numbers suggest that rural migrants have a higher tendency to engage in entrepreneurial activities than their urban counterparts with urban hukou and their rural hukou counterparts who remain in the countryside.

Besides sociodemographic characteristics such as gender, age, educational attainment and membership in Chinese Communist Party (CCP) that are standard in entrepreneurship research, we also construct three important variables informed by prior studies: entrepreneurial activities: social networks, personal drive, and community trust.

Social Networks. Previous works investigating the relationship between social networks and entrepreneurship in the Chinese context have largely drawn on questions asking the number of friends from whom respondents are able to receive help, or with whom respondents have exchanged gifts during Chinese holidays (Liu and Huang 2016; Yueh 2009; Zhang and Zhao 2015). We use a similar but more direct question in CLDS that asks the number of friends one can receive financial assistance for at least 5,000 yuan (a little over \$700) to form the strength of his/her social networks. Unlike "help" framed in a generic sense, offering financial "loans" can be viewed as a stronger sign of camaraderie and close connections in the Chinese culture. Hence, we expect a direct linkage between the strength of one's social networks and the number of friends he/she can receive financial assistance. With respondents placing themselves in one of the following categories: zero friends, one to three friends, four to six friends, seven to nine friends, and ten or more friends, social network is approximated by using the mid-point interpolation of the bins. ${ }^{5}$

Personal Drive. Willingness towards uncertainty, motivation to seek economic opportunities, and determination to overcome hardships are likely important traits possessed by entrepreneurs (Djankov et al.

\footnotetext{
${ }^{5}$ Value $0(10)$ is assigned when respondents choose the first (last) category.
} 
2006). The strength of one's personal drive is thus drawn from a variable in CLDS that asks the extent to which respondents agree with the statement, "Even if I feel sick or have justified reasons to pause for work, I still do my utmost to finish the task." While options are categorically worded as strongly disagree, disagree, agree, and strongly agree, we treat them as if it were an interval variable and present it in the model linearly.

Community Trust. Communities serve as important incubators to entrepreneurship. A positive and supporting environment would therefore be especially important for migrants who are not rooted in the urban fabrics. To establish a measure reflecting the positive role of communities, we rely on a question that asks respondents the extent to which they trust community members, with respondents placing themselves in one of the following categories: not at all, not too much, on average, trust, and trust very much. Like with personal drive, we treat community trust as an interval variable.

[Table 3 about here]

Descriptive statistics comparing entrepreneurs and non-entrepreneurs from two waves of CLDS are presented in Table 3. Overall, entrepreneurs are more likely to be men, and the average person in both years is in his/her late 30s irrespective of entrepreneurial status. Individuals who are entrepreneurs are more likely to be middle-school graduates and less likely to be middle school dropouts or college graduates, which is consistent with prior findings (Liu and Huang 2016; Yueh 2009). Entrepreneurs are less likely to be CCP members, rural or urban residents, but are more likely to be rural migrants and have a larger network of friends willing to offer financial assistance. Entrepreneurs demonstrate a higher degree of drive and motivation and are more likely to hold a positive perception of communities compared to non-entrepreneurs in 2012. Taken together, the summary statistics generated from CLDS are in many ways similar to the mean statistics produced by alternative datasets such as the Chinese Household Income Project, thus providing a degree of confidence to the validity of the dataset.

\section{Methodology}


We use two sets of regression analyses to examine the relationship between individual demographic

characteristics, social network, personal drive, and community trust and his/her entrepreneurial status. To assess the heterogeneous effects of these factors on the probability of being entrepreneurs, we stratify the sample into three groups: rural residents, urban residents, and rural migrants. In the first set of analyses, we use the standard logit-regression model in the 2012 and the 2014 CLDS cross-sectional datasets respectively. The logit regression takes the form:

$$
\operatorname{Ln}\left(\frac{\text { Entre }_{i, p}}{1-\text { Entre }_{i, p}}\right)=\mathrm{a}_{0}+\sum_{i} \Gamma \mathbf{X}_{\mathrm{i}, \mathrm{p}}+\mathrm{a}_{1} \mathrm{UR}_{\mathrm{i}, \mathrm{p}}+\mathrm{a}_{2} \mathrm{RM}_{\mathrm{i}, \mathrm{p}}+\mathrm{a}_{3} \mathrm{Z}_{\mathrm{i}, \mathrm{p}}+\boldsymbol{\gamma}_{\mathrm{p}}+\varepsilon_{\mathrm{i}, \mathrm{p}}
$$

Where Entre $_{i, p}$ denotes the probability that individual $i$ in province $p$ is an entrepreneur, and $\mathbf{X}_{\mathrm{i}, \mathrm{p}}$ is the vector containing individual demographic characteristics (dummy variable for gender, a linear term for age, education attainment with middle-school graduates being the reference group, and CCP membership). UR $R_{i, p}$ and RM $_{i, p}$ indicate individual's urban resident and rural migrant status, with rural residents being the reference group. The vector $Z_{i, p}$ includes social networks, personal drive, and community trust, which are defined in the preceding section. Provincial fixed effects are included, absorbing time-invariant factors at the provincial level that are potential correlates of individual's social networks and community trust and of one's entrepreneurial status. Instead of reporting the logit regression coefficients, we report the average partial effects associated with each covariate and cluster standard errors at the family level throughout (Bertrand et al. 2004).

In the standard specification used in the benchmark models (specification 1 and many prior studies), entrepreneurial status is modeled as functions of individual's contemporaneous characteristics. In the second set of analysis, we capitalize on the longitudinal nature of CLDS and improve on our first set of analysis as well as prior studies in addressing the endogeneity concerns embedded in the relationship between individual characteristics and his/her decision in entrepreneurship. Specifically, we model one's decision to engage in private ventures in 2014 conditional on his/her non-entrepreneurial status in 2012 as a function of his/her 
characteristics in 2012. In so doing we convert (1) into a model of entrepreneurial entry. As above, we use standard logit-regression model and cluster standard errors at the family level ${ }^{6}$

$$
\operatorname{Ln}\left(\frac{\text { Entre }_{i, p}}{1-\text { Entre }_{i, p}} \text { Entre }_{i, p, 2012}=0\right)=\mathrm{b}_{0}+\sum_{i} \Gamma \mathbf{X}_{\mathrm{i}, \mathrm{p}}+\mathrm{b}_{1} \mathrm{UR}_{\mathrm{i}, \mathrm{p}}+\mathrm{b}_{2} \mathrm{RM}_{\mathrm{i}, \mathrm{p}}+\mathrm{b}_{3} \mathrm{Z}_{\mathrm{i}, \mathrm{p}}+\boldsymbol{\gamma}_{\mathrm{p}}+\varepsilon_{\mathrm{i}, \mathrm{p}}
$$

Where $\frac{\text { Entre }_{i, p}}{1-\text { Entre }_{i, p}} \mid$ Entr $_{i, p, 2012}=0$ denotes the odds that individual $i$ is an entrepreneur in 2014 conditional being a non-entrepreneur in 2012. All the other variables are defined in the same ways as in specification (1).

Dropping entrepreneurs in 2012 leaves only those who entered self-employment between 2012 and 2014 and allows us to assess the relationship between prior individual characteristics and his/her decision in choosing the entrepreneurial path. We further stratify the sample into the same three groups and run specification (2) on each of them to examine the heterogeneous effect of these factors. In this way, we examine whether rural migrants are more or less likely than rural and urban residents to become entrepreneurs, and whether social networks, personal drive, and community trust are predicative of their entrepreneurial entry.

\section{Empirical Results}

\section{Cross-sectional Analysis on Being Entrepreneur}

[Table 4 about here]

Results for the full sample and stratified samples from 2012 and 2014 are presented in Table 4. Focusing on results from the full sample, we find that, on average, men are more likely than women to be entrepreneurs. Specifically, men's probability of being entrepreneurs is 6 percent higher than women's probability of being entrepreneurs relative to the sample mean. While older individuals are more likely to be entrepreneurs, the difference is rather small. Consistent with what we've seen in Table 3, individuals with higher or lower degrees are less likely to engage in entrepreneurial activities than those graduated with middle school degrees. In particular, results suggest that getting a college degree lowers one's likelihood of becoming entrepreneurs by 3

\footnotetext{
${ }^{6}$ Statistical conclusions from specification (1) and (2) are not changed by clustering standard errors at the province level. Results are available upon request.
} 
percentage points or 25 percent in 2012, and by 7 percentage points or by 60 percent in 2014 . The negative association between human capital and starting private businesses, though contrary to findings in the Western literature, is not surprising in the Chinese context as "iron bowl" jobs characterized by career stability continue to be valued by highly-educated workers in the labor market. CCP members are found to be less likely to engage in entrepreneurial activities than non-CCP members, though the linkage weakened in 2014. Compared to rural residents, rural migrants are 45-50 percent more likely to be entrepreneurs. Social networks and personal drive are positively correlated with entrepreneurship, and yet both see their magnitude reduced in 2014. We observe virtually no relationship between trusts in community members and one's probability of entrepreneurship over the full sample.

We observe some level of heterogeneity when stratifying the sample into rural residents, urban residents, and rural migrants. Gender and age are by and large consistent with the story told in the full sample: men are more likely than women to be entrepreneurs, so are older individuals compared to the younger ones. The relationship between educational attainment and entrepreneurship among rural residents and urban residents is similar to that in the full sample. Among rural migrants, however, having a college degree is negatively related to entrepreneurship, which is statistically significant in 2014. Social networks remain positively associated with entrepreneurship in the full and the stratified samples for all groups. The positive relationship between personal drive and entrepreneurship is consistent only among urban residents, suggesting an important role determination plays in making urban residents avert the enticement of "iron bowl" jobs and choose entrepreneurship.

Interestingly, a higher level of community trust is particularly salient to rural migrants' entrepreneurial decisions while it is not significant in the full sample or the other subgroups. The positive relationship suggests the pivotal role community environment and community perception serves in rural migrants' entrepreneurial choices. As newcomers in the cities, they face challenges and constraints in both the housing market and the labor market and it takes time and efforts to get adjusted to city life. Like the "ethnic enclave theories" would suggest in the U.S context (Sanders and Nee 1987), migrant workers are more likely to be assimilated into 
friendly and welcoming neighborhoods with community members they can trust and support their entrepreneurial aspirations, some of whom might be their fellow migrants.

\section{Panel Data Analysis on Entrepreneurial Entry}

While cross-sectional analysis demonstrates the differential entrepreneurial tendencies across groups and their associated factors, its static nature precludes examination of entry dynamics over time. Tracing the change in entrepreneurial status from 2012 and 2014, panel B of Table 2 shows the rate of entrepreneurial entry and exit for the full sample and the three sub-samples. Entrepreneurial entry captures a transition from other employments or unemployment to entrepreneurship and entrepreneurial exit refers to the opposite. Over the two-year periods, 6 percent of individuals become entrepreneurs while 44 percent of entrepreneurs transitioned out of their businesses. Across three sub-groups, rural migrants exhibit the highest entry rate (12.7 percent), followed by urban residents (6.2 percent) and rural residents (6.2 percent). Rural migrants also have the lowest exit rate (32.2 percent) compared to the other two groups. These numbers show interesting dynamics in terms of entrepreneurial transition, especially the relatively high exit rate of entrepreneurial activities, signaling the risky nature of this path.

[Table 5 about here]

Table 5 presents estimates of the effects of individual characteristics on one's entrepreneurial entry for the full and the stratified samples. As shown in the first column, most variables maintain consistent signs with those in the cross-sectional analyses under the full sample, though many of their magnitude are reduced. Rural migrants' higher entry rate is robust even after controlling for other relevant variables while urban residents are slightly more likely than rural residents to form new businesses. The significant effect of personal drive and social network on individuals' probability of becoming entrepreneurs disappeared. There are three possible reasons. First, personal drive and social networks tested in the cross-sectional setting are in fact endogenous, leading to an exaggerated effect on entrepreneurial formation. Second, while personal drive and social network are important explanatory factors, their effects on the decision to start private ventures are easily dwarfed by 
external forces, such as the accessibility of financial loans, the macroeconomic conditions, and the political environment, ultimately driving both to zero. Third, the nil effects may be due to the attenuation bias caused by measurement errors. While we are unable to single out and claim the cause(s), the stark contrast to what many previous studies have suggested using cross-sectional datasets, including those shown in Table 4, calls for further analysis. Understanding the exact contribution of personal drive and social networks in entrepreneurial formation in the Chinese context deserves much further research.

In subsample analyses, we observe some interesting patterns unique to rural migrants. The negative effect of age seems to exist for rural residents only and not for urban residents or rural migrants. The impact of personal drive stands out among rural migrants, suggesting that personal determination and endurance is a particularly valuable trait for this group. Specifically, for each one level increase in the four-level scale of personal drive, there is a 5 percentage point rise in rural migrants' probability of becoming entrepreneurs. Here again, community trust serves as an important facilitator of entrepreneurial entry for rural migrants. If we are to assume that trusts act as a two-way effect, rural migrants who cast a higher level of trust in community members might also have a better chance of starting their own businesses.

\section{Firm Performance Analysis}

In an attempt to gauge the economic impact of migrant owned businesses in cities and how they compare with the businesses established by their urban resident and rural resident counterparts, we provide descriptive statistics comparing several key indicators: the number of years running the business, the total number of employees hired, the total amount of salary paid over the past month, and the initial capital invested for the business. We adjust the first three variables as follows: negatives were recoded as zero and values above the 95th percentile were recoded as the 95th percentile. The variable initial capital invested was originally coded categorically as follows: 1 - less than $5 \mathrm{~K} ; 2-5 \mathrm{~K}$ to $10 \mathrm{~K} ; 3-10 \mathrm{~K}$ to $50 \mathrm{~K} ; 4-50 \mathrm{~K}$ to $100 \mathrm{~K} ; 5-100 \mathrm{~K}$ to $500 \mathrm{~K}$; $6-500 \mathrm{~K}$ to 1 million; and 7 - more than 1 million. Following the strategy for social network, we transformed 
the initial capital variable by assigning the median value of each category to the original category with the exception that the first category is assigned value 5000 and the last category assigned value 1 million.

[Table 6 about here]

Table 6 presents summary statistics for the three groups of business owners using data in 2012 and 2014 separately. In 2012, rural migrant owned businesses have an average of 7.6 years in business as compared to an average of 8.3 years in 2014. The total number of employees rural migrants had was 6.2 in 2012, compared to the 5.7 employees they hired in 2014. The average total salary paid over the past month had a substantial increase from 12,200 yuan in 2012 to 19,300 yuan in 2014. The average initial capital invested into business more than doubled in 2014 compared to 2012 for rural migrants. Contrary to expectations discussed earlier, the business scale indicators do not portray an image of small, petty street vendors among rural migrants; rather sizable businesses comparable to their urban resident counterparts.

[Table 7 about here]

Table 7 further shows the industrial distribution for three groups of entrepreneurs. More than half of rural migrants established their businesses in the Wholesale, Retail and Food industry in 2012 and close to half had their businesses established in the same sector in 2014. These main street industries might have low barriers to entry, thereby attracting rural migrant entrepreneurs. It is also worth noting that the rural migrant entrepreneurs' representation in high-end service sectors - finance, insurance, real estate and social welfare had experienced a fast growth over the course of two-year period, from 1 percent to 17 percent. This suggests the increasing diversity of migrant-owned businesses and their entry into professional and social service industries.

\section{Conclusion and Discussion}

When China's economic outlook hinges upon a robust development of the private sector, it is of importance to understand what facilitates the transition into self-employment and what incentivizes them to stay in this sector. As the national economy continues to grow and diversify, China's private sector will draw 
growing recognition. Migrant workers in cities are an important labor force in China's urbanization process. Our study finds that rural migrants in China exhibit a higher tendency to engage in entrepreneurial activities than their urban counterparts who live in cities as well as rural counterparts who remain in the rural areas.

Several significant factors stand out in analyzing the entrepreneurial activities of migrants. Being a CCP member and having either low educational attainment (lower than middle school diploma) or high educational attainment (some college or more) seems to deter the chances of entrepreneurial entry. Having broader social network, a higher degree of personal drive and motivation to the contrary facilitates business startup. One notable finding unique to the rural migrants is the significant and positive role community trust plays in their entrepreneurial career. This finding echoes discussions on the importance of communities, especially ethnic communities or enclaves in supporting immigrants' business operations through the provision of clientele, workers and familial environments. It is arguable that community trust and support is also highly valuable for these rural newcomers to Chinese cities in their business activities. This linkage has not been empirically tested or theoretically established in the Chinese context before and the exact mechanisms through which it operates provide an area for future research.

Improving upon past cross-sectional studies, we use panel data analysis to further test rural migrants' entrepreneurial entry between 2012 and 2014. We found that rural migrants had the highest entrepreneurial entry rate and lowest entrepreneurial exit rate, as compared to urban residents and rural residents. Most of the results we established in cross-sectional analyses prove to be robust though the significant effect of social networks disappeared, suggesting that it might be endogenous to the question at hand. When comparing the performance of firms owned by rural migrants and the other two groups, we observe that these businesses tend to concentrate in main-street type sectors (wholesale, retail and food) and less in other industries, with comparable business duration, employment and initial capital investment, to other businesses. Their overall business indicators also improved from 2012 to 2014, with the exception of number of employees. These results run counter to the anecdotal stereotype of rural migrant-owned businesses in the cities and suggest the important contributions they make to the business landscape and economic vibrancy of the cities they live in. 
The findings in this research paint a new picture of migrants' entrepreneurial development in China, from a higher tendency to enter entrepreneurship to a strong firm performance. As China's economic growth continue to rely on market forces and private sector, it is important for the government to carry out tailored entrepreneurial policies geared towards rural migrants, who are more active and motivated to become entrepreneurs. As suggested in this research, both community and personal assets are vital for migrants' entrepreneurial development. Under the nation's strong push for "mass entrepreneurship and innovation," more specific policies and programs need to be designed to help China's migrant entrepreneurs to maximize their entrepreneurial drive and facilitate their business growth. As new policies along these lines, the Chinese government plans to offer support for entrepreneurial development, such as welfare coverage in the areas of

social security, housing, education and medical services for rural migrants. A cross-regional cost sharing system will be created to link migrants' hometown and current residency so that occupational training, financial support and community services could be provided with more sufficient fiscal sources. More research is needed to identify the challenges the migrants face in their entrepreneurial activities as well as to evaluate the relative effectiveness of these new policy initiatives.

\section{Acknowledgements}

Lin Ye appreciates the financial support from Chinese Ministry of Education Key Research Center Major Project 16JJD630013. 


\section{References}

Angrist, J. D. \& Pischke, J. S. (2008). Mostly Harmless Econometrics: An Empiricist's Companion. Princeton University Press.

Barrett, G. A., Jones, T. P. \& McEvoy, D. (1996). Ethnic minority business: Theoretical discourse in Britain and North America. Urban Studies 33 (4-5): 783-809.

Basu, A. (1998). An exploration of entrepreneurial activity among Asian small businesses in Britain. Small Business Economics 10(4):313 - 326.

Bertrand, M., Duflo, E. \& Mullainathan, S. (2004). How much should we trust differences-in-differences estimates? Quarterly Journal of Economics 119 (1):249-275.

Borjas, J. (1986). The self-employment experience of immigrants. The Journal of Human Resources, 21(4): 485-506.

Chan, K. W. \& Buckingham, W. (2008). Is China abolishing the hukou system? The China Quarterly 195 (6): $582-606$.

Chen, J. (2015). Creating the environment for the strategic industrial restructuring and "mass entrepreneurship mass innovation" policy in Zhejiang. Zhejiang Economics, 7:11-13.

Constant, A. and Zimmermann, K. (2006). The making of entrepreneurs in Germany: Are native men and immigrant alike? Small Business Economics, 42 (3):279-300.

Cui, Y, Nahm, D. and Tani, M. (2013). Self-employment in China: Are Rural Migrant Workers and Urban Residents Alike? IZA Working paper No. 7191.

Djankov, S., Qian, Y., Roland, G. \& Zhuravskaya, E. (2006). Who Are China's Entrepreneurs? American Economic Review 96 (2):348-352.

Fairlie, R. W. (2012). Immigrant Entrepreneurs and Small Business owners, and Their Access to Financial Capital. Washington, D. C.; Office of Advocacy, Small Business Administration.

Kerr, S. P, \& Kerr, W. R. (2016). Immigrant Entrepreneurship, NBER working paper No. 22385. 
Kloosterman, R. C. (2003). Creating opportunities: Policies aimed at increasing openings for immigrant entrepreneurs in the Netherlands. Entrepreneurship \& Regional Development 15 (2): 167-181.

Kim, P. H., Aldrich, H. E. \& Keister, L. A. (2006). Access (not) denied: The impact of financial, human, and cultural capital on entrepreneurial entry in the United States. Small Business Economics 27(1):5-22.

Li, B. (2006). Floating population or urban citizens? Status, social provision and circumstances of rural-urban migrants in China. Social Policy \& Administration, 40(2): 174-195.

Light, I. (1972). Ethnic enterprise in America. Berkeley, CA: University of California Press.

Liu, C. Y. (2012). Intrametropolitan opportunity structure and the self-employment of Asian and Latino immigrants. Economic Development Quarterly 26 (2): 178-192.

Liu, C. Y. (2014). The causes and dynamics of minority entrepreneurial entry. Journal of Developmental Entrepreneurship, 17 (1):125003-1-23.

Liu, C. Y. \& Huang, X. (2016). The rise of urban entrepreneurs in China: Capital endowments and entry dynamics. Growth and Change 47 (1): 32-52.

Liu, C. Y., Miller, J. \& Wang, Q. (2014). Ethnic enterprises and community development. GeoJournal 79 (5): $565-576$.

Liu, Y. Li, Z., Liu, Y. \& Chen, H. (2015). Growth of rural migrant enclaves in Guangzhou, China: Agency, everyday practice and social mobility. Urban Studies 52(16):3086-3105.

Peroni, C., Riillo, C.A. F. \& Sarracino, F. (2016). Entrepreneurship and immigration: Evidence from GEM Luxembourg. Small Business Economics 46 (4): 639-656.

Rath, J., \& Kloosterman, R. (2000). Outsiders' business: A critical review of research on immigrant entrepreneurship. International Migration Review 34(3): 657-681.

Sanders, J., \& Nee, V. (1987). Limits of ethnic solidarity in the enclave economy. American Sociological Review 52 (6): 745-773.

The State Council. (2015). Opinions on the Policy Promoting "Mass Entrepreneurship and Mass Innovation". Retrieved from http://www.gov.cn/zhengce/content/2015-06/16/content_9855.htm, August 7, 2017. 
The State Council. (2014). March 17. The National New Type Urbanization Plan 2014-2020. Retrieved from http://www.gov.cn/zhengce/2014-03/16/content_2640075.htm, August 7, 2017.

Waldinger, R., Aldrich, H. \& Ward, R. (1990). Ethnic entrepreneurs: Immigrant business in industrial societies. Newbury Park, CA: Sage Publications.

Wang, Q. \& Liu, C. Y. (2015). Transnational Activities of Immigrant-Owned Firms and Their Performances in the USA. Small Business Economics 44 (2): 345-359.

Wilson, L. \& Portes, A. (1980). Immigrant enclaves: An analysis of the immigrant labor market experience of Cubans in Miami. American Journal of Sociology 86 (2): 295-319.

Yueh, L. (2009). China's entrepreneurs. World Development 37 (4):778-786.

Yueh, L. (2012). Legal development, financial repression, and entrepreneurship in a marketizing economy. The Chinese Economy 45 (4): 39-82.

Yuengert, A. M. (1995). Testing hypotheses of immigrant self-employment. Journal of Human Resources 30 (1): 194-204.

Zhang, J, \& Zhao, Z. (2015). Social-family network and self-employment: evidence from temporary ruralurban migrants in China. IZA Journal of Labor \& Development 4 (1):1-21.

Zhou, M. (2004). Revisiting ethnic entrepreneurship: Convergences, controversies, and conceptual advancements. International Migration Review 38(3): 1040-1074. 
Table 1 Sample Share and Entrepreneurship Rate by Province or

Direct Municipality by Year

\begin{tabular}{|c|c|c|c|c|c|}
\hline \multicolumn{3}{|c|}{2012} & \multicolumn{3}{|c|}{2014} \\
\hline $\begin{array}{c}\text { Province/ } \\
\text { Direct municipality }\end{array}$ & $\begin{array}{c}\text { Share of } \\
\text { Sample }(\%)\end{array}$ & $\begin{array}{c}\text { Entrepreneurship } \\
\text { Rate }(\%)\end{array}$ & $\begin{array}{c}\text { Province/ } \\
\text { Direct municipality }\end{array}$ & $\begin{array}{c}\text { Share of } \\
\text { Sample (\%) }\end{array}$ & $\begin{array}{c}\text { Entrepreneurship } \\
\text { Rate }(\%)\end{array}$ \\
\hline Guangdong & 11.26 & 13 & Guangdong & 10.91 & 15 \\
\hline Henan & 7.83 & 12 & Henan & 6.42 & 9 \\
\hline Shandong & 6.67 & 9 & Sichuan & 5.96 & 14 \\
\hline Sichuan & 5.64 & 15 & Shandong & 5.78 & 16 \\
\hline Hunan & 5.04 & 13 & Zhejiang & 5.33 & 17 \\
\hline Hubei & 4.65 & 17 & Hunan & 5.18 & 13 \\
\hline Hebei & 4.54 & 5 & Hebei & 5.12 & 10 \\
\hline Jiangsu & 4.43 & 11 & Fujian & 4.71 & 18 \\
\hline Zhejiang & 4.14 & 19 & Hubei & 4.62 & 11 \\
\hline Fujian & 3.82 & 21 & Jiangsu & 4.5 & 17 \\
\hline Yunan & 3.78 & 13 & Guangxi & 3.91 & 6 \\
\hline Guangxi & 3.76 & 3 & Yunan & 3.8 & 7 \\
\hline Anhui & 3.69 & 7 & Liaoning & 3.45 & 11 \\
\hline Liaoning & 3.55 & 13 & Anhui & 3.42 & 17 \\
\hline Shaanxi & 3.4 & 8 & Shanxi & 3.23 & 9 \\
\hline Heilongjiang & 3.33 & 8 & Heilongjiang & 3.17 & 7 \\
\hline Jiangxi & 3.21 & 24 & Jiangxi & 3.03 & 21 \\
\hline Shanxi & 2.88 & 14 & Xinjiang & 2.76 & 8 \\
\hline Jilin & 2.79 & 9 & Jilin & 2.44 & 11 \\
\hline Xinjiang & 2.53 & 10 & Shaanxi & 2.43 & 7 \\
\hline Guizhou & 1.95 & 10 & Gansu & 2.11 & 8 \\
\hline Gansu & 1.75 & 7 & Guizhou & 1.98 & 8 \\
\hline Inner Mongolia & 1.36 & 11 & Inner Mongolia & 1.74 & 9 \\
\hline Chongqing & 1.21 & 12 & Tianjin & 1.13 & 9 \\
\hline Tianjin & 0.66 & 6 & Chongqing & 1.03 & 12 \\
\hline Shanghai & 0.62 & 5 & Shanghai & 0.53 & 5 \\
\hline Beijing & 0.56 & 5 & Beijing & 0.51 & 3 \\
\hline Ningxia & 0.49 & 13 & Ningxia & 0.42 & 9 \\
\hline Qinghai & 0.47 & 7 & Qinghai & 0.38 & 13 \\
\hline Total & 100 & 12 & Total & 100 & 12 \\
\hline$N$ & & 16,253 & $N$ & & 23,594 \\
\hline
\end{tabular}

Note: Entrepreneurs include employers and the self-employed. Entrepreneurship rates except the total rate are calculated within each Province/Direct municipality. Survey weight applied.

According to the 2012 and 2014 National Bureau of Statistics of China, the entrepreneurship rate were 11\% and 13\% respectively.

Source: Authors' calculation of CLDS 2012 and 2014. 
Entrepreneurship Rate

CLDS 2012

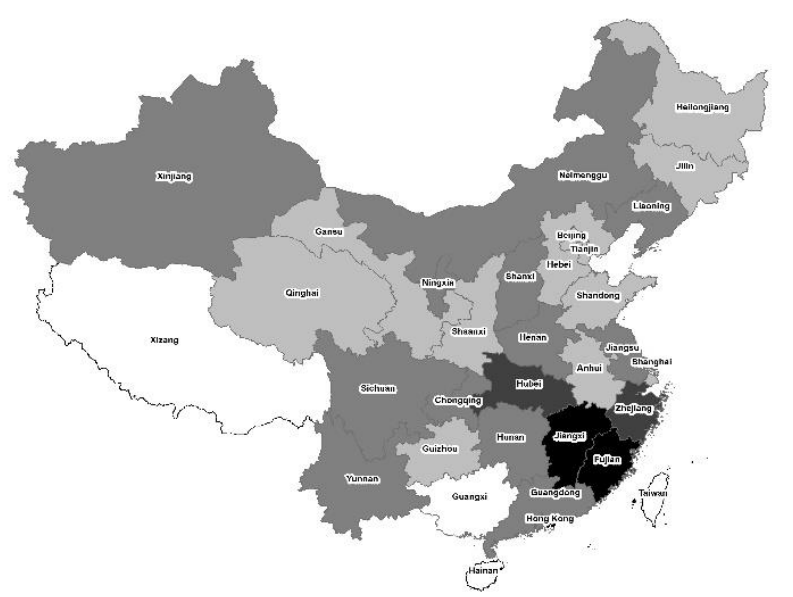

\section{Entrepreneurship Rate}

CLDS 2014

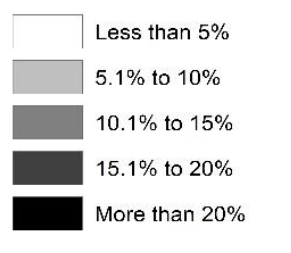

8

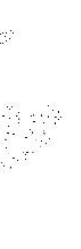

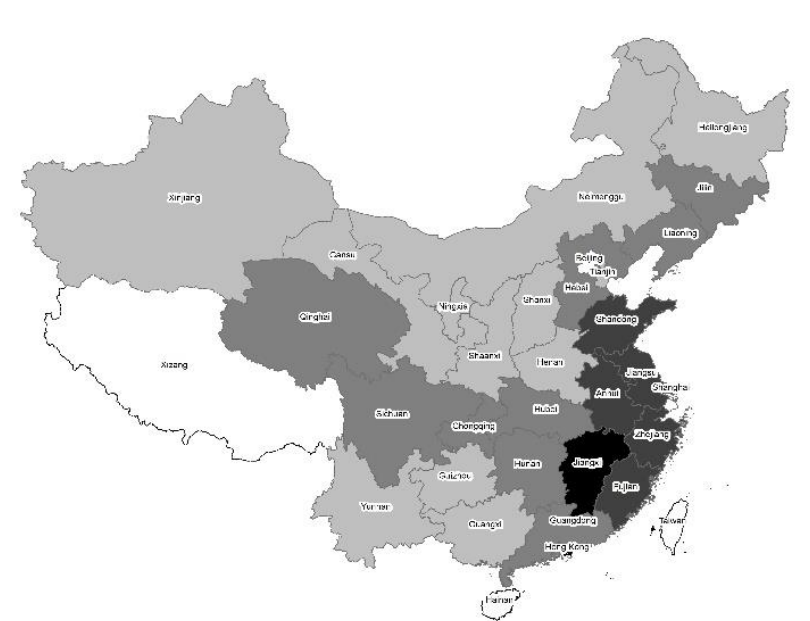

Less than $5 \%$ $5.1 \%$ to $10 \%$

$5.1 \%$ to $10 \%$
$10.1 \%$ to $15 \%$

$15.1 \%$ to $20 \%$

More than 20\%

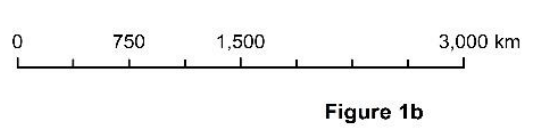

Figure 1a

$\Lambda$

Figure 1 Entrepreneurship Rate by Province/Direct Municipality 
Table 2 Entrepreneurship Rates by Year and by Group

\section{Rural Residents Urban Residents Rural Migrants}

\section{Panel A (Cross-sections)}

Entrepreneurship Rate in 2012

10.9

9.7

16.9

Entrepreneurship Rate in 2014

11.4

10.8

19.1

\section{Panel B (Panel)}

Entrepreneurial Entry

6.2

6.2

12.7

Entrepreneurial Exit

43.9

38.4

32.2

Note: Entrepreneurs include employers and the self-employed. Survey weight applied.

Rural residents are individuals with rural hukou living in rural area.

Urban residents are individuals with urban hukou living in urban area.

Rural migrants are individuals with rural hukou living in urban area.

Individuals who were not entrepreneurs in 2012 but became entrepreneurs in 2014 are defined as "Entrepreneurial

Entry." "Entrepreneurial Exit" refers to the opposite. 
Table 3 Summary Statistics: Entrepreneurs vs. Non-Entrepreneurs

\begin{tabular}{|c|c|c|c|c|}
\hline & \multicolumn{2}{|c|}{2012} & \multicolumn{2}{|c|}{2014} \\
\hline & $\begin{array}{c}\text { Non-entrepreneurs } \\
\text { (1) }\end{array}$ & $\begin{array}{c}\text { Entrepreneurs } \\
(2) \\
\end{array}$ & $\begin{array}{c}\text { Non-entrepreneurs } \\
\text { (3) }\end{array}$ & $\begin{array}{c}\text { Entrepreneurs } \\
\text { (4) }\end{array}$ \\
\hline Male & $\begin{array}{c}0.53 \\
{[0.50]}\end{array}$ & $\begin{array}{l}0.68^{* * *} \\
{[0.47]}\end{array}$ & $\begin{array}{c}0.49 \\
{[0.50]}\end{array}$ & $\begin{array}{l}0.64^{* * *} \\
{[0.48]}\end{array}$ \\
\hline Age & $\begin{array}{c}36.21 \\
{[13.44]}\end{array}$ & $\begin{array}{l}38.56^{* *} \\
{[9.90]}\end{array}$ & $\begin{array}{c}38.03 \\
{[13.62]}\end{array}$ & $\begin{array}{l}38.93^{* *} \\
{[10.19]}\end{array}$ \\
\hline Middle school dropouts & $\begin{array}{c}0.35 \\
{[0.48]}\end{array}$ & $\begin{array}{l}0.31^{* *} \\
{[0.46]}\end{array}$ & $\begin{array}{c}0.25 \\
{[0.43]}\end{array}$ & $\begin{array}{l}0.18^{* * *} \\
{[0.38]}\end{array}$ \\
\hline Middle school graduates & $\begin{array}{c}0.38 \\
{[0.49]}\end{array}$ & $\begin{array}{l}0.47^{* * * *} \\
{[0.50]}\end{array}$ & $\begin{array}{c}0.44 \\
{[0.50]}\end{array}$ & $\begin{array}{l}0.58^{* * *} \\
{[0.49]}\end{array}$ \\
\hline High school graduates & $\begin{array}{c}0.12 \\
{[0.33]}\end{array}$ & $\begin{array}{c}0.10^{*} \\
{[0.29]}\end{array}$ & $\begin{array}{c}0.12 \\
{[0.32]}\end{array}$ & $\begin{array}{c}0.11 \\
{[0.31]}\end{array}$ \\
\hline Some college or more & $\begin{array}{c}0.15 \\
{[0.36]}\end{array}$ & $\begin{array}{c}0.13 \\
{[0.34]}\end{array}$ & $\begin{array}{c}0.19 \\
{[0.39]}\end{array}$ & $\begin{array}{c}0.13^{* * *} \\
{[0.34]}\end{array}$ \\
\hline CCP member & $\begin{array}{c}0.08 \\
{[0.27]}\end{array}$ & $\begin{array}{l}0.05^{* * *} \\
{[0.21]}\end{array}$ & $\begin{array}{c}0.06 \\
{[0.24]}\end{array}$ & $\begin{array}{l}0.04^{* * *} \\
{[0.19]}\end{array}$ \\
\hline Rural residents & $\begin{array}{c}0.64 \\
{[0.48]}\end{array}$ & $\begin{array}{l}0.59^{* *} \\
{[0.49]}\end{array}$ & $\begin{array}{c}0.59 \\
{[0.49]}\end{array}$ & $\begin{array}{l}0.55^{* *} \\
{[0.50]}\end{array}$ \\
\hline Urban residents & $\begin{array}{c}0.21 \\
{[0.41]}\end{array}$ & $\begin{array}{l}0.17^{* *} \\
{[0.37]}\end{array}$ & $\begin{array}{c}0.26 \\
{[0.44]}\end{array}$ & $\begin{array}{l}0.22^{* *} \\
{[0.41]}\end{array}$ \\
\hline Rural migrants & $\begin{array}{c}0.10 \\
{[0.30]}\end{array}$ & $\begin{array}{l}0.15^{* * *} \\
{[0.36]}\end{array}$ & $\begin{array}{c}0.12 \\
{[0.32]}\end{array}$ & $\begin{array}{l}0.20^{* * *} \\
{[0.40]}\end{array}$ \\
\hline Social network & $\begin{array}{c}2.35 \\
{[2.63]}\end{array}$ & $\begin{array}{l}3.44^{* * *} \\
{[3.02]}\end{array}$ & $\begin{array}{c}2.83 \\
{[2.86]}\end{array}$ & $\begin{array}{l}3.50^{* * *} \\
{[3.03]}\end{array}$ \\
\hline Personal drive & $\begin{array}{c}2.92 \\
{[0.56]}\end{array}$ & $\begin{array}{l}2.99^{* * *} \\
{[0.56]}\end{array}$ & $\begin{array}{c}2.90 \\
{[0.54]}\end{array}$ & $\begin{array}{l}2.93^{*} \\
{[0.54]}\end{array}$ \\
\hline Community trust & $\begin{array}{c}3.54 \\
{[0.84]}\end{array}$ & $\begin{array}{l}3.59^{\dagger} \\
{[0.79]}\end{array}$ & $\begin{array}{c}3.62 \\
{[0.84]}\end{array}$ & $\begin{array}{c}3.62 \\
{[0.82]}\end{array}$ \\
\hline$N$ & 11,481 & 1,533 & 19,535 & 2,730 \\
\hline
\end{tabular}

Note: Entrepreneurs include employers and the self-employed. Standard deviations are shown in bracket. Survey weight applied.

$\dagger p<0.10, * p<0.05, * * p<0.01, * * * p<0.001$

CCP stands for Chinese Communist Party.

Definitions on rural residents, urban residents, and rural migrants are the same as in Table 2.

Social network, defined in the text, denotes the number of friends who can offer financial assistance.

Personal drive, defined in the text, ranges from 1 (Highly disagree) to 4 (Highly agree).

Community trust, defined in the text, ranges from 1 (Highly disagree) to 5 (Highly agree). 
Table 4 Logistic Regression Results on Probability of Being an Entrepreneur

\begin{tabular}{|c|c|c|c|c|c|c|c|c|}
\hline \multirow[t]{2}{*}{$\begin{array}{l}D V: \text { individual is an } \\
\text { entrepreneur }\end{array}$} & \multicolumn{4}{|c|}{2012} & \multicolumn{4}{|c|}{2014} \\
\hline & All & $\begin{array}{c}\text { Rural } \\
\text { residents }\end{array}$ & $\begin{array}{l}\text { Urban } \\
\text { residents }\end{array}$ & $\begin{array}{c}\text { Rural } \\
\text { migrants }\end{array}$ & All & $\begin{array}{c}\text { Rural } \\
\text { residents }\end{array}$ & $\begin{array}{l}\text { Urban } \\
\text { residents }\end{array}$ & $\begin{array}{c}\text { Rural } \\
\text { migrants }\end{array}$ \\
\hline Male & $\begin{array}{c}0.058^{* * * *} \\
(0.007)\end{array}$ & $\begin{array}{l}0.064^{* * * *} \\
(0.008)\end{array}$ & $\begin{array}{c}0.026^{\dagger} \\
(0.014)\end{array}$ & $\begin{array}{c}0.112^{* * * *} \\
(0.022)\end{array}$ & $\begin{array}{c}0.061^{* * *} \\
(0.006)\end{array}$ & $\begin{array}{c}0.078^{* * *} \\
(0.007)\end{array}$ & $\begin{array}{l}0.029^{*} \\
(0.011)\end{array}$ & $\begin{array}{l}0.055^{* *} \\
(0.019)\end{array}$ \\
\hline Age & $\begin{array}{c}0.002^{\text {*** }} \\
(0.000)\end{array}$ & $\begin{array}{l}0.001^{* *} \\
(0.000)\end{array}$ & $\begin{array}{c}0.002^{* * * *} \\
(0.001)\end{array}$ & $\begin{array}{l}0.004^{* * * *} \\
(0.001)\end{array}$ & $\begin{array}{l}0.001^{* * *} \\
(0.000)\end{array}$ & $\begin{array}{c}0.000 \\
(0.000)\end{array}$ & $\begin{array}{l}0.001^{*} \\
(0.000)\end{array}$ & $\begin{array}{l}0.003^{* *} \\
(0.001)\end{array}$ \\
\hline MS dropouts & $\begin{array}{c}-0.040^{* * * *} \\
(0.010)\end{array}$ & $\begin{array}{l}-0.028^{*} \\
(0.011)\end{array}$ & $\begin{array}{l}-0.055^{\dagger} \\
(0.031)\end{array}$ & $\begin{array}{l}-0.016 \\
(0.029)\end{array}$ & $\begin{array}{c}-0.057^{* * * *} \\
(0.007)\end{array}$ & $\begin{array}{c}-0.051^{* * *} \\
(0.009)\end{array}$ & $\begin{array}{c}-0.052^{* *} \\
(0.019)\end{array}$ & $\begin{array}{l}-0.015 \\
(0.028)\end{array}$ \\
\hline HS graduates & $\begin{array}{c}-0.045^{\text {**** }} \\
(0.012)\end{array}$ & $\begin{array}{l}-0.034^{*} \\
(0.016)\end{array}$ & $\begin{array}{c}-0.077^{* * *} \\
(0.021)\end{array}$ & $\begin{array}{c}-0.032 \\
(0.033)\end{array}$ & $\begin{array}{c}-0.049^{* * *} \\
(0.010)\end{array}$ & $\begin{array}{c}-0.056^{* * *} \\
(0.012)\end{array}$ & $\begin{array}{c}-0.067^{* * *} \\
(0.018)\end{array}$ & $\begin{array}{c}0.007 \\
(0.031)\end{array}$ \\
\hline College or more & $\begin{array}{l}-0.032^{*} \\
(0.014)\end{array}$ & $\begin{array}{l}-0.012 \\
(0.022)\end{array}$ & $\begin{array}{l}-0.053^{*} \\
(0.021)\end{array}$ & $\begin{array}{c}-0.043 \\
(0.036)\end{array}$ & $\begin{array}{c}-0.067^{\text {*** }} \\
(0.010)\end{array}$ & $\begin{array}{c}-0.066^{* * *} \\
(0.014)\end{array}$ & $\begin{array}{c}-0.063^{* * *} \\
(0.018)\end{array}$ & $\begin{array}{c}-0.088^{* *} \\
(0.027)\end{array}$ \\
\hline CCP member & $\begin{array}{c}-0.086^{* * * *} \\
(0.020)\end{array}$ & $\begin{array}{l}-0.031^{+} \\
(0.018)\end{array}$ & $\begin{array}{l}-0.132^{* *} \\
(0.043)\end{array}$ & $\begin{array}{c}-0.220^{* *} \\
(0.084)\end{array}$ & $\begin{array}{c}-0.065^{* * * *} \\
(0.017)\end{array}$ & $\begin{array}{l}-0.012 \\
(0.025)\end{array}$ & $\begin{array}{c}-0.118^{* * *} \\
(0.024)\end{array}$ & $\begin{array}{l}-0.090 \\
(0.057)\end{array}$ \\
\hline Urban residents & $\begin{array}{l}-0.005 \\
(0.013)\end{array}$ & & & & $\begin{array}{c}0.016 \\
(0.010)\end{array}$ & & & \\
\hline Rural migrants & $\begin{array}{c}0.054^{* * *} \\
(0.011)\end{array}$ & & & & $\begin{array}{c}0.063^{* * *} \\
(0.010)\end{array}$ & & & \\
\hline Social network & $\begin{array}{c}0.012^{* * *} \\
(0.001)\end{array}$ & $\begin{array}{l}0.011^{* * * *} \\
(0.001)\end{array}$ & $\begin{array}{c}0.015^{* * *} \\
(0.003)\end{array}$ & $\begin{array}{c}0.015^{* * *} \\
(0.004)\end{array}$ & $\begin{array}{c}0.007^{* * *} \\
(0.001)\end{array}$ & $\begin{array}{c}0.007^{* * *} \\
(0.001)\end{array}$ & $\begin{array}{l}0.004^{*} \\
(0.002)\end{array}$ & $\begin{array}{c}0.013^{* * *} \\
(0.004)\end{array}$ \\
\hline Personal drive & $\begin{array}{l}0.020^{* *} \\
(0.007)\end{array}$ & $\begin{array}{l}0.017^{*} \\
(0.008)\end{array}$ & $\begin{array}{l}0.034^{*} \\
(0.015)\end{array}$ & $\begin{array}{c}0.030 \\
(0.019)\end{array}$ & $\begin{array}{c}0.015^{*} \\
(0.006)\end{array}$ & $\begin{array}{c}0.004 \\
(0.008)\end{array}$ & $\begin{array}{l}0.024^{*} \\
(0.010)\end{array}$ & $\begin{array}{c}0.016 \\
(0.020)\end{array}$ \\
\hline Community trust & $\begin{array}{c}0.002 \\
(0.004)\end{array}$ & $\begin{array}{l}-0.001 \\
(0.005)\end{array}$ & $\begin{array}{l}-0.013 \\
(0.008)\end{array}$ & $\begin{array}{l}0.036^{*} \\
(0.015)\end{array}$ & $\begin{array}{l}-0.005 \\
(0.004)\end{array}$ & $\begin{array}{l}-0.006 \\
(0.005)\end{array}$ & $\begin{array}{l}-0.004 \\
(0.009)\end{array}$ & $\begin{array}{l}0.030^{*} \\
(0.012)\end{array}$ \\
\hline Mean of DV & 0.12 & 0.11 & 0.10 & 0.17 & 0.12 & 0.11 & 0.11 & 0.19 \\
\hline Province FEs & Yes & Yes & Yes & Yes & Yes & Yes & Yes & Yes \\
\hline$N$ & 12,869 & 8,195 & 2,606 & 1,479 & 21,809 & 12,356 & 6,024 & 2,699 \\
\hline
\end{tabular}

Note: Standard errors, clustered at the family level, are shown in parenthesis. Survey weight applied.

$\dagger p<0.10, * p<0.05, * * p<0.01, * * * p<0.001$

Individuals younger than 16 or older than 70 are excluded from analyses.

MS stands for middle school and HS stands for high school

Other variables are defined the same as in Table 3 
Table 5 - Panel Analysis Results on Entrepreneurial Entry by Group, 2012-4

\begin{tabular}{|c|c|c|c|c|}
\hline DV: becoming an entrepreneur & All & Rural residents & Urban residents & Rural migrants \\
\hline Male & $\begin{array}{c}0.039^{* * *} \\
(0.007)\end{array}$ & $\begin{array}{c}0.045^{* * * *} \\
(0.008)\end{array}$ & $\begin{array}{c}0.006 \\
(0.018)\end{array}$ & $\begin{array}{l}0.095^{*} \\
(0.037)\end{array}$ \\
\hline Age & $\begin{array}{c}-0.001^{\dagger} \\
(0.000)\end{array}$ & $\begin{array}{c}-0.001^{* * *} \\
(0.000)\end{array}$ & $\begin{array}{c}0.001 \\
(0.001)\end{array}$ & $\begin{array}{c}0.000 \\
(0.001)\end{array}$ \\
\hline Middle school dropouts & $\begin{array}{l}-0.012 \\
(0.010)\end{array}$ & $\begin{array}{l}-0.015 \\
(0.011)\end{array}$ & $\begin{array}{c}0.015 \\
(0.034)\end{array}$ & $\begin{array}{c}0.037 \\
(0.046)\end{array}$ \\
\hline High school graduates & $\begin{array}{l}-0.024^{\dagger} \\
(0.013)\end{array}$ & $\begin{array}{l}-0.021 \\
(0.016)\end{array}$ & $\begin{array}{c}-0.031 \\
(0.031)\end{array}$ & $\begin{array}{c}0.025 \\
(0.069)\end{array}$ \\
\hline Some college or more & $\begin{array}{c}-0.046^{* * *} \\
(0.011)\end{array}$ & $\begin{array}{l}-0.031^{\dagger} \\
(0.017)\end{array}$ & $\begin{array}{l}-0.038 \\
(0.025)\end{array}$ & $\begin{array}{l}-0.062 \\
(0.055)\end{array}$ \\
\hline CCP member & $\begin{array}{l}-0.036^{*} \\
(0.015)\end{array}$ & $\begin{array}{c}-0.012 \\
(0.018)\end{array}$ & $\begin{array}{l}-0.081^{*} \\
(0.033)\end{array}$ & $\begin{array}{c}0.036 \\
(0.068)\end{array}$ \\
\hline Urban residents & $\begin{array}{l}0.021^{\dagger} \\
(0.013)\end{array}$ & & & \\
\hline Rural migrants & $\begin{array}{c}0.043^{* * *} \\
(0.013)\end{array}$ & & & \\
\hline Social network & $\begin{array}{c}0.000 \\
(0.001)\end{array}$ & $\begin{array}{c}0.002 \\
(0.002)\end{array}$ & $\begin{array}{l}-0.005 \\
(0.004)\end{array}$ & $\begin{array}{l}-0.001 \\
(0.006)\end{array}$ \\
\hline Personal drive & $\begin{array}{l}-0.006 \\
(0.006)\end{array}$ & $\begin{array}{l}-0.005 \\
(0.006)\end{array}$ & $\begin{array}{l}-0.007 \\
(0.019)\end{array}$ & $\begin{array}{c}0.050^{\dagger} \\
(0.025)\end{array}$ \\
\hline Community trust & $\begin{array}{c}0.007 \\
(0.005)\end{array}$ & $\begin{array}{c}0.007 \\
(0.005)\end{array}$ & $\begin{array}{l}-0.017 \\
(0.013)\end{array}$ & $\begin{array}{l}0.047^{*} \\
(0.021)\end{array}$ \\
\hline Province FEs & Yes & Yes & Yes & Yes \\
\hline$N$ & 6,769 & 4,885 & 1,238 & 478 \\
\hline
\end{tabular}

Note: Standard errors, clustered at the family level, are shown in parenthesis. Survey weight applied.

$\dagger p<0.10, * p<0.05, * * p<0.01, * * * p<0.001$

Sample has been restricted to individuals who participated in the surveyed in both years and who were NOT entrepreneurs in 2012. Individuals younger than 16 or older than 70 are excluded from analyses.

All RHS variables are in 2012 values. Column 1 uses the full sample. Column 2 restricts the sample to those who had rural hukou in 2012 and lived in rural areas in 2012. Column 3 restricts the sample to those who had urban hukou in 2012 and lived in urban areas in 2012. Column 4 restricts the sample to those who had rural hukou in 2012 and lived in urban areas in 2012. 
Table 6 - Summary Statistics for Firm Performance Indicators

\begin{tabular}{|c|c|c|c|c|c|c|}
\hline & \multicolumn{3}{|c|}{2012} & \multicolumn{3}{|c|}{2014} \\
\hline & $\begin{array}{c}\text { Rural } \\
\text { residents }\end{array}$ & $\begin{array}{c}\text { Urban } \\
\text { residents }\end{array}$ & $\begin{array}{c}\text { Rural } \\
\text { migrants }\end{array}$ & $\begin{array}{c}\text { Rural } \\
\text { residents }\end{array}$ & $\begin{array}{c}\text { Urban } \\
\text { residents } \\
\end{array}$ & $\begin{array}{c}\text { Rural } \\
\text { migrants }\end{array}$ \\
\hline Number of years running the business & $\begin{array}{c}8.72 \\
{[7.12]}\end{array}$ & $\begin{array}{c}6.90 \\
{[5.38]}\end{array}$ & $\begin{array}{c}7.62 \\
{[5.77]}\end{array}$ & $\begin{array}{c}7.25 \\
{[6.20]}\end{array}$ & $\begin{array}{c}6.86 \\
{[6.39]}\end{array}$ & $\begin{array}{c}8.28 \\
{[5.79]}\end{array}$ \\
\hline Total number of employees & $\begin{array}{c}6.22 \\
{[6.98]}\end{array}$ & $\begin{array}{c}5.30 \\
{[6.32]}\end{array}$ & $\begin{array}{c}6.23 \\
{[7.14]}\end{array}$ & $\begin{array}{c}7.07 \\
{[9.24]}\end{array}$ & $\begin{array}{c}6.46 \\
{[8.42]}\end{array}$ & $\begin{array}{c}5.66 \\
{[7.34]}\end{array}$ \\
\hline Total salary paid over the past month $(/ 10,000)$ & $\begin{array}{c}1.83 \\
{[2.90]}\end{array}$ & $\begin{array}{c}2.21 \\
{[3.47]}\end{array}$ & $\begin{array}{c}1.22 \\
{[2.11]}\end{array}$ & $\begin{array}{c}2.66 \\
{[4.12]}\end{array}$ & $\begin{array}{c}2.00 \\
{[3.20]}\end{array}$ & $\begin{array}{c}1.93 \\
{[3.18]}\end{array}$ \\
\hline Initial capital $(/ 10,000)^{\mathrm{a}}$ & $\begin{array}{c}9.26 \\
{[19.00]}\end{array}$ & $\begin{array}{c}12.78 \\
{[19.41]}\end{array}$ & $\begin{array}{c}9.81 \\
{[14.29]}\end{array}$ & $\begin{array}{c}18.73 \\
{[22.14]}\end{array}$ & $\begin{array}{c}24.81 \\
{[31.58]}\end{array}$ & $\begin{array}{c}23.86 \\
{[32.37]}\end{array}$ \\
\hline
\end{tabular}

Note: survey weight applied. Standard deviation in bracket.

Definitions on rural residents, urban residents, and rural migrants are the same as in Table 2.

a: Employers were asked how much they invested to start the business. The variable was categorically coded as follows: 1: less than $5 \mathrm{~K} ; 2: 5 \mathrm{~K}-10 \mathrm{~K} ; 3: 10 \mathrm{~K}-50 \mathrm{~K} ; 4$ : $50 \mathrm{~K}-$ $100 \mathrm{~K} ; 5: 100 \mathrm{~K}-500 \mathrm{~K} ; 6: 500 \mathrm{~K}-1$ million; 7: more than 1 million. We recoded the variable by assigning the median value of each category to the original category with the exception that the first category is assigned value 5000 and the last category assigned value 1,000,000.

Variables "number of years running the business," "total number of employees," and "total salary paid over the past month (/¥ 10,000)" are adjusted as follows: negatives were recoded as zero and values above the $95^{\text {th }}$ percentile were recoded as the $95^{\text {th }}$ percentile 
Table 7 - Industry Distribution for Three Groups of Entrepreneurs

\begin{tabular}{|c|c|c|c|c|c|c|}
\hline & \multicolumn{3}{|c|}{2012} & \multicolumn{3}{|c|}{2014} \\
\hline & $\begin{array}{l}\text { Rural } \\
\text { residents } \\
(\%)\end{array}$ & $\begin{array}{l}\text { Urban } \\
\text { residents } \\
(\%)\end{array}$ & $\begin{array}{l}\text { Rural } \\
\text { migrants } \\
(\%)\end{array}$ & $\begin{array}{l}\text { Rural } \\
\text { residents } \\
(\%)\end{array}$ & $\begin{array}{l}\text { Urban } \\
\text { residents } \\
(\%)\end{array}$ & $\begin{array}{l}\text { Rural } \\
\text { migrants } \\
(\%)\end{array}$ \\
\hline Agriculture and Mining & 12.68 & 2.80 & 3.85 & 8.87 & 1.51 & 3.32 \\
\hline $\begin{array}{l}\text { Manufacturing, Raw } \\
\text { materials, and Metal and } \\
\text { Mechanical }\end{array}$ & 12.19 & 14.33 & 12.72 & 9.81 & 3.06 & 5.71 \\
\hline Construction & 19.81 & 4.63 & 8.89 & 21.91 & 8.01 & 9.36 \\
\hline $\begin{array}{l}\text { Geological prospecting, } \\
\text { Utility, Transportation } \\
\text { and Telecommunication }\end{array}$ & 9.88 & 5.83 & 9.84 & 10.46 & 8.33 & 6.95 \\
\hline $\begin{array}{l}\text { Wholesale, Retail, and } \\
\text { Food }\end{array}$ & 30.15 & 46.26 & 51.26 & 26.85 & 43.85 & 46.09 \\
\hline $\begin{array}{l}\text { Finance, Insurance, Real } \\
\text { estate, and Social } \\
\text { welfare }\end{array}$ & 11.03 & 15.66 & 10.31 & 12.35 & 23.36 & 17.02 \\
\hline $\begin{array}{l}\text { Education, Culture and } \\
\text { Arts, Entertainment, and } \\
\text { Consulting }\end{array}$ & 1.07 & 6.98 & 1.88 & 0.80 & 2.25 & 1.33 \\
\hline $\begin{array}{l}\text { Public administration, } \\
\text { Social organizations, and } \\
\text { Others }\end{array}$ & 3.20 & 3.51 & 1.26 & 8.95 & 9.62 & 10.22 \\
\hline$N$ & 810 & 237 & 275 & 1,073 & 454 & 426 \\
\hline
\end{tabular}

Note: Survey weight applied.

Definitions on rural residents, urban residents, and rural migrants are the same as in Table 2. 